\title{
Steady-State Study of Inhibitory Effect of Nitrite on Myeloperoxidase Catalytic Activity by Hydrogen Peroxide Biosensor
}

\author{
Yahya R. Tahboub, ${ }^{1,{ }^{*}}$ Husam M. Abu-Soud ${ }^{2}$ \\ ${ }^{1}$ Department of Applied Chemistry, Jordan University of Science and Technology, \\ Irbid 22110, Jordan \\ ${ }^{2}$ Department of Obstetrics and Gynecology, The CS Mott Center for Human Growth and \\ Development, Wayne State University, School of Medicine, Detroit, MI, USA
}

Received 8 June 2009; accepted 15 December 2009

\begin{abstract}
Myeloperoxidase (MPO) is a neutrophil enzyme that employs hydrogen peroxide $\left(\mathrm{H}_{2} \mathrm{O}_{2}\right)$ to catalyze the oxidation of halides and thiocyanate to their respective hypohalous acids. In this study, the inhibitory effect of nitrite $\left(\mathrm{NO}_{2}{ }^{-}\right)$on MPO-catalytic activity was investigated electrochemically. $\mathrm{H}_{2} \mathrm{O}_{2}$ consumption during steady-state catalysis was monitored amperometrically by a carbon fiber based $\mathrm{H}_{2} \mathrm{O}_{2}$-biosensor at 25 ${ }^{\circ} \mathrm{C}$. Optimized initial concentrations were $50 \mathrm{nM}$ MPO, $10 \mu \mathrm{M} \mathrm{H}_{2} \mathrm{O}_{2}$, and a selected halide or thiocyanate concentration from physiological range. Under these conditions, reactions were monophasic and rapid (complete $\mathrm{H}_{2} \mathrm{O}_{2}$ consumption occurs in $<10 \mathrm{~s}$ ). As concentration of $\mathrm{NO}_{2}{ }^{-}$increases, reactions change to biphasic (rapid step followed by a slow step) and both steps have been inhibited by $\mathrm{NO}_{2}{ }^{-}$. Our results confirmed the inhibitory effect of $\mathrm{NO}_{2}^{-}$and demonstrated for the first time that $\mathrm{NO}_{2}^{-}$is a strong inhibitor towards MPO-catalyzed oxidation of iodide and bromide; and a weak inhibitor towards MPO-catalyzed oxidation of chloride and thiocyanate.
\end{abstract}

Keywords: nitric oxide, nitrite, myeloperoxidase, catalytic activity, $\mathrm{H}_{2} \mathrm{O}_{2}$-biosensor.

\section{Introduction}

Nitric oxide (nitrogen monoxide, NO) is ever-present signaling molecule involved in the regulation of many processes, including activities of the cardiovascular, nervous and immune systems [1-4]. Stimulation of NO synthases during inflammatory processes represents a defense mechanism against invading

\footnotetext{
* Corresponding author. E-mail address: tahboub@just.edu.jo
} 
organisms, although excessive formation of $\mathrm{NO}$ has been implicated in host tissue injury $[5,6]$. Nitrite $\left(\mathrm{NO}_{2}{ }^{-}\right)$is observed to accumulate upon nitric oxide synthase activation in many inflammatory diseases [7] and $\mathrm{NO}_{2}{ }^{-}$concentrations can be higher in tissues than those measured in plasma [8,9]. In healthy human subjects, $\mathrm{NO}_{2}{ }^{-}$can be detected at levels $0.5-3.6 \mu \mathrm{M}$ in plasma $[10,11], \sim 15 \mu \mathrm{M}$ in respiratory tract lining fluids [12], 30-210 $\mu \mathrm{M}$ in saliva and $0.40-60 \mu \mathrm{M}$ in gastric juice [13]. Extra cellular $\mathrm{NO}_{2}^{-}$levels markedly increase during inflammatory processes reflecting increased NO production. For instance, a serum level of 36 $\mu \mathrm{M}$ has been reported in human immunodeficiency virus-infected patients with interstitial pneumonia [8].

Myeloperoxidase (MPO), a member of mammalian peroxidases, displays a crucial difference (within a wide range of biological processes) in its unique ability in catalyzing the $\mathrm{H}_{2} \mathrm{O}_{2}$-dependent peroxidation of halides and pseudo halides to produce antimicrobial agents and hypohalous acids [14-19].

The simplified mechanism that governs the catalytic activity of MPO can be represented by the classic peroxidases catalytic cycle, which is represented by Equations 1-4,

$$
\begin{gathered}
\text { MPO-Fe(IV) }=\mathrm{O}^{++\pi}+\mathrm{X}^{-} \rightarrow \text { MPO-Fe(III) }+\mathrm{HOX} \\
\mathrm{MPO}-\mathrm{Fe}(\mathrm{IV})=\mathrm{O}^{\cdot+\pi}+\mathrm{AH}_{2} \rightarrow \underset{\text { MPO-Fe(IV) }=\mathrm{O}+\mathrm{AH}^{\cdot}}{\text { Compound II }} \\
\mathrm{MPO}-\mathrm{Fe}(\mathrm{IV})=\mathrm{O}+\mathrm{AH}_{2} \rightarrow \mathrm{MPO}-\mathrm{Fe}(\mathrm{III})+\mathrm{AH}^{\cdot}
\end{gathered}
$$

$\mathrm{H}_{2} \mathrm{O}_{2}$ reacts rapidly and reversibly with ground state (MPO-Fe(III)) and generates a ferryl $\pi$ cation radical (MPO-Fe(IV) $=\mathrm{O}^{\cdot+\pi}$ ) intermediate compound I [20,21]. Compound I is capable of oxidizing either halides and pseudo halides ( $\mathrm{X}^{-}$) through a $2 \mathrm{e}^{-}$transition generating the ground state and the corresponding hypohalous acid (HOX). During turnover, compound $\mathrm{I}$ is also converted to peroxidase intermediate compound II $(\mathrm{MPO}-\mathrm{Fe}(\mathrm{IV})=\mathrm{O})$ and $\mathrm{MPO}-\mathrm{Fe}(\mathrm{III})$ ,respectively, because of the presence of exogenous $\left(\mathrm{AH}_{2}\right)$ or endogenous electron donors [20-23]. Compound II is inactive in 2e oxidation of $\mathrm{X}^{-}$and is a longer lived intermediate whose decay to ground state is considered to be the rate-limiting step during steady-state catalysis [20,21]. Acceleration in compound II formation and decay has been noted with a series of organic and inorganic substrates [22-25].

The effect of $\mathrm{NO}_{2}{ }^{-}$on catalytic activity of MPO was reported by a number of research groups [26-32]. It has been demonstrated that MPO and other peroxidases can oxidize $\mathrm{NO}_{2}^{-}$to a species capable of nitrating tyrosine and tyrosyl residues in protein [26-30]. Also, it was reported that $\mathrm{NO}_{2}^{-}$is a poor substrate for ground state MPO and an inhibitor for its chlorination activity, and it is oxidized by two one-electron steps in the MPO peroxidase cycle [31,32]. Most of these studies were based on pre-steady state conditions and/or steady- 
state conditions with optical spectroscopic monitoring. In most cases, larger than normal plasma concentrations of MPO and/or $\mathrm{NO}_{2}^{-}$were employed. The reason for doing that was to optimize conditions where measurable changes in absorbance at selected wavelengths (430 $\mathrm{nm}$ for compound I decay and $455 \mathrm{~nm}$ for compound II formation and decay) could be monitored.

Steady-state methods with electrochemical monitoring have advantages over other methods. In such methods a targeted reactant or product could be detected by oxidation or reduction at the surface of a selective electrochemical biosensor. However, lack of biosensors with enough sensitivity, selectivity and short response time limited their employment. Kettle et al. employed a conventional $\mathrm{H}_{2} \mathrm{O}_{2}$ electrode for monitoring steady-state loss of $\mathrm{H}_{2} \mathrm{O}_{2}$ in MPO-catalyzed reactions with halides, and other one electron reductants [31-35]. Lower sensitivity, long calibration procedure and interferences from produced hypohalous acids limited the ability of collected data from predicting kinetic models. In most cases, initial rates were calculated and employed for either comparison between reductants or as supportive to other methods.

Recently, combination- $\mathrm{H}_{2} \mathrm{O}_{2}$ biosensors based on a flexible activated carbon fiber sensing electrode coated with a propriety membrane that enhances $\mathrm{H}_{2} \mathrm{O}_{2}$ detection were developed [37,38]. Such electrodes have better sensitivity than conventional electrodes, and a relatively short response time $(2 \mathrm{~s})$.

In this study, we employed a carbon fiber based $\mathrm{H}_{2} \mathrm{O}_{2}$-biosensor to study the inhibitory effect of $\mathrm{NO}_{2}^{-}$on catalytic activity of MPO towards oxidation of halides and thiocyanate $\left(\mathrm{Cl}^{-}, \mathrm{Br}^{-}, \mathrm{I}^{-}\right.$and $\left.\mathrm{SCN}^{-}\right)$under respective physiological concentrations. All experiments were based on monitoring the time course decay of the amperometric $\mathrm{H}_{2} \mathrm{O}_{2}$ initial signal throughout the MPO-catalyzed reaction. Our results provided comprehensive electrochemical evidence that $\mathrm{NO}_{2}{ }^{-}$inhibits the MPO-catalyzed oxidation of halides and thiocyanate. Observed inhibition was strong for iodide and bromide, and weak for chloride and thiocyanate.

\section{Experimental \\ Reagents}

Chemicals used for preparation of buffer, stock and standard solutions were of analytical grade reagents and purchased from Sigma. Phosphate buffer, $100 \mathrm{mM}$ and $\mathrm{pH} 7.00$, was prepared by mixing appropriate volumes of $0.10 \mathrm{M} \mathrm{NaH}_{2} \mathrm{PO}_{4}$ and $0.10 \mathrm{M} \mathrm{Na}_{2} \mathrm{HPO}_{4}$ to achieve pH 7.00. A $1.00 \mathrm{mM} \mathrm{H}_{2} \mathrm{O}_{2}$ solution was freshly prepared from stock solutions prepared by sequential dilutions from $30 \% \mathrm{H}_{2} \mathrm{O}_{2}$ solution. Standard solutions of halides $\left(\mathrm{Cl}^{-}, \mathrm{Br}^{-}, \mathrm{I}^{-}\right), \mathrm{SCN}^{-}$and $\mathrm{NO}_{2}^{-}$were prepared by sequential dilutions from their respective sodium salts. All solutions were bubbled with high purity $\mathrm{N}_{2}$ gas before use.

\section{MPO preparation}

MPO was purified from detergent extracts from human leukocytes. The purity of isolated MPO was established by demonstrating a Reinheitszahl (RZ) value of > $0.85\left(\mathrm{~A}_{430} / \mathrm{A}_{280}\right)$ via SDS-PAGE analysis [39-40]. MPO concentration was determined spectrophotometrically utilizing molar extension coefficients of 
89.000 and $112.000 \mathrm{M}^{-1} \mathrm{~cm}^{-1}$ per heme $(\lambda=430 \mathrm{~nm})$ [40]. A $30 \mu \mathrm{M}$ MPO solution was freshly prepared by diluting measured amounts with buffer.

\section{Electrochemical measurements}

Amperometric measurements were performed by Apollo 4000 free radical analyzer (WPI, Sarasota, FL, USA). The biosensor was ISO-HPO-100 (also from $\mathrm{WPI}$ ), that is a $100 \mu \mathrm{M}$ tip diameter hydrogen peroxide micro sensor. The sensor design was based on a flexible carbon fiber sensing electrode coated with a selective membrane that enhances $\mathrm{H}_{2} \mathrm{O}_{2}$ detection. The sensor incorporates combination electrode technology. Applied potential was set at $400 \mathrm{mV}$. The sensor has sensitivity better than $2 \mathrm{pA} / \mathrm{nM}$, detection limit of $20 \mathrm{nM}$ and a baseline drift of $1 \mathrm{pA} / \mathrm{min}$ [38]. Measurements and reactions were monitored in a thermostated measurement chamber (also from WPI) and all experiments were performed at room temperature $\left(25^{\circ} \mathrm{C}\right)$. The electrode was calibrated daily in presence of $100 \mu \mathrm{M} \mathrm{NO}_{2}{ }^{-}$and selected physiological concentrations of halides and thiocyanate. Electrode calibrations were based on successive addition of 5 $\mu \mathrm{L}$ from $1.0 \mathrm{mM} \mathrm{H} \mathrm{O}_{2}$ solution to $3.0 \mathrm{~mL}$ of $100 \mathrm{mM}$ phosphate buffer solution ( $\mathrm{pH}$ 7.00) pre-incubated with $100 \mu \mathrm{M} \mathrm{NO}{ }_{2}^{-}$and a selected physiological concentration of halide or thiocyanate in the chamber. After each addition, the current (nA) was recorded and calibration curves between current (nA) and $\left[\mathrm{H}_{2} \mathrm{O}_{2}\right](\mu \mathrm{M})$ were constructed by linear least-squares method. Amperometric monitoring of $\mathrm{H}_{2} \mathrm{O}_{2}$ during MPO-catalyzed reaction experiments was performed as follows: for each experiment, $3.00 \mathrm{~mL}$ of $100 \mathrm{mM}$ phosphate buffer solution containing $30 \mu \mathrm{M}$ ethylenediaminetetraacetic acid (EDTA) were placed in the measurement chamber. For blank study measurements, varied concentrations of $\mathrm{NO}_{2}{ }^{-}(0-100) \mu \mathrm{M}$ were pre-incubated with buffer. For the effect of nitrite measurements, a selected physiological concentration of halide or thiocyanate $\left(100 \mathrm{mM} \mathrm{Cl}^{-}, 60 \mu \mathrm{M} \mathrm{Br}^{-}, 10 \mu \mathrm{M} \mathrm{I}^{-}, 50 \mu \mathrm{M} \mathrm{SCN}^{-}\right)$and varied concentrations of $\mathrm{NO}_{2}^{-}$(0-100 ) $\mu \mathrm{M}$ were pre-incubated with buffer solution in the chamber. For the effect of chloride measurements, $100 \mu \mathrm{M} \mathrm{NO}_{2}{ }^{-}$and varied concentrations of $\mathrm{Cl}^{-}$(0-100) $\mathrm{mM}$ were pre-incubated with buffer solution in the chamber. The electrode was immersed and magnetic stirrer was turned on at fixed moderate speed. Continuous amperometric monitoring started after the addition of $30 \mu \mathrm{L}$ $\mathrm{H}_{2} \mathrm{O}_{2}(10 \mu \mathrm{M})$. Reactions started after addition of $5.0 \mu \mathrm{L}$ MPO solution $(50 \mathrm{nM})$ and were allowed to proceed until complete decay of initial current signal. $\mathrm{H}_{2} \mathrm{O}_{2}$ concentrations $(\mu \mathrm{M})$ versus time (s) plots were obtained by setting the initial current signal to $10 \mu \mathrm{M} \mathrm{H}_{2} \mathrm{O}_{2}$.

\section{Results}

\section{Validation of measurements}

Calibration curves in phosphate buffer solution (blank solution) were linear in the studied range $\left(0.00-10.00 \mu \mathrm{M} \mathrm{H}_{2} \mathrm{O}_{2}\right)$ with a regression equation of $\mathrm{Y}=(2.21 \pm$ $0.05) \mathrm{X}+(0.11 \pm 0.02), \mathrm{R}^{2}=0.998$, where $\mathrm{Y}$ is the current $(\mathrm{nA})$ and $\mathrm{X}$ is $\left[\mathrm{H}_{2} \mathrm{O}_{2}\right]$ $(\mu \mathrm{M})$. Coefficient of variation of slope $(\mathrm{CV})$ is $2.3 \%$ and intercept was equivalent to $0.05 \pm 0.01 \mu \mathrm{M} \mathrm{H}_{2} \mathrm{O}_{2}$. Limit of detection (LOD) calculated at $\mathrm{S} / \mathrm{N}=$ 
3, was $0.025 \mu \mathrm{M}$. These parameters did not vary significantly $(<5 \%)$ upon preincubation of blank solution with physiological concentrations of halides, thiocyanate and nitrite. Stability of the electrode was demonstrated by performing calibration measurements daily. Proper use and maintenance of electrode may extend its life up to six months.

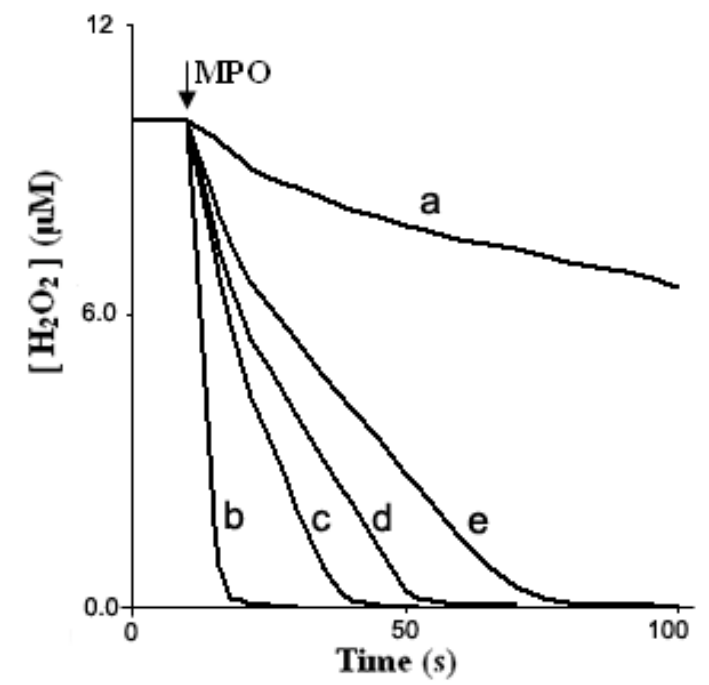

Figure 1. Effect of $\mathrm{NO}_{2}^{-}$on MPO-catalytic activity towards oxidation of $\mathrm{Cl}^{-} \cdot \mathrm{H}_{2} \mathrm{O}_{2}$ consumption plots as a function of $\mathrm{NO}_{2}^{-}$. Reactions were started by the addition of 50 $\mathrm{nM}$ MPO to $10 \mu \mathrm{M} \mathrm{H}_{2} \mathrm{O}_{2}$ in $100 \mathrm{mM}$ phosphate buffer, $\mathrm{pH} 7.0$, containing $30 \mu \mathrm{M}$ EDTA (a) pre-incubated with $100 \mathrm{mM} \mathrm{Cl}^{-}$(b) and 25 (c), 50 (d), $100 \mu \mathrm{M} \mathrm{NO}_{2}^{-}$(e). Reactions were arried at $25{ }^{\circ} \mathrm{C}$. Plots are average of four replicates.

\section{Optimization of initial concentrations}

The major objective of this work was to conduct a steady-state electrochemical study of the inhibitory effect of nitrite on the catalytic activity of MPO towards oxidation of $\mathrm{Cl}^{-}, \mathrm{Br}^{-}, \mathrm{I}^{-}$and $\mathrm{SCN}^{-}$. Pre-steady state studies reported that accumulation and stability of compound II by $\mathrm{NO}_{2}^{-}$is the main factor of inhibition of the catalytic reaction [31,32]. It also was documented that $\mathrm{H}_{2} \mathrm{O}_{2}$ reacts with compound I to either liberate oxygen gas (catalase) or reduce it to compound II $[35,41]$. Thus, a blank study was conducted to optimize initial MPO and $\mathrm{H}_{2} \mathrm{O}_{2}$ concentrations that minimize and estimate the catalase reaction (consumption of $\mathrm{H}_{2} \mathrm{O}_{2}$ through oxidation of $\mathrm{H}_{2} \mathrm{O}_{2}$ to $\mathrm{O}_{2}$ ). Additionaly, another study was conducted to select initial halide or $\mathrm{SCN}^{-}$concentration (preferably from physiological range) that when incubated with optimized concentrations of MPO, $\mathrm{H}_{2} \mathrm{O}_{2}$ and in absence of nitrite, compound II is not formed during turnover (oxidation of $\mathrm{X}^{-}$to $\mathrm{HOX}$ ). Results were evaluated by referring to monophasic and biphasic nature of the peroxidation cycle. We assumed that the time course of $\mathrm{H}_{2} \mathrm{O}_{2}$ consumption is monophasic when total decay of initial $\mathrm{H}_{2} \mathrm{O}_{2}$ signal occurs in $<10 \mathrm{~s}$ (equations 1 and 2 in peroxidase cycle). Time course is biphasic when turnover occurs in two sequential and separable steps, a rapid step (first $10 \mathrm{~s}$ ) followed by a slower step. The first step (fast) is similar to the monophasic step and represents turnover before significant accumulation of compound II. The 
second step (slow) represents turnover after accumulation of compound II (partial conversion of MPO to compound II, equations 1-3 in peroxidase cycle). Blank decay plots were biphasic. Rates of consumption of $\mathrm{H}_{2} \mathrm{O}_{2}$ from both steps increase by increasing MPO and $\mathrm{H}_{2} \mathrm{O}_{2}$ concentrations due to dominance of catalase reaction [35]. A typical decay plot at selected $\mathrm{H}_{2} \mathrm{O}_{2}(10 \mu \mathrm{M})$ and MPO $(50 \mathrm{nM})$ is presented in Fig. 1 (a). Blank decay plots did not change upon incubation of blank samples with $\mathrm{NO}_{2}{ }^{-}$(up to $100 \mu \mathrm{M}$ ) and with $10 \mu \mathrm{M}$ of hypohalous acid. Calculated rates from blank studies were $0.10 \mu \mathrm{M} / \mathrm{s}$ for first step and $0.03 \mu \mathrm{M} / \mathrm{s}$ for second step. Pre-incubation of blank samples with increasing concentrations of halides or $\mathrm{SCN}^{-}$(absence of $\mathrm{NO}_{2}^{-}$) has increased both rates and decay plots were monophasic at $\mathrm{Cl}^{-}>15 \mathrm{mM}, \mathrm{Br}^{-}>50 \mu \mathrm{M}, \mathrm{I}^{-}>5.0$ $\mu \mathrm{M}$ and $\mathrm{SCN}^{-}>40 \mu \mathrm{M}$ (data not shown). Selected initial concentrations, 100 $\mathrm{mM} \mathrm{Cl}-60 \mu \mathrm{M} \mathrm{Br}^{-}, 10 \mu \mathrm{M} \mathrm{I}^{-}$and $50 \mu \mathrm{M} \mathrm{SCN}^{-}$were from physiological range except for $\mathrm{I}^{-}$(plasma range $\sim 1.0 \mu \mathrm{M}$ ) due to stoichiometric reasons (same concentration of $\mathrm{H}_{2} \mathrm{O}_{2}$.

\section{Inhibitory effect of $\mathrm{NO}_{2}^{-}$on MPO-catalytic activity towards oxidation of $\mathrm{Cl}^{-}$}

Chloride is assumed to be the physiological substrate for MPO due to its high concentration (100-140 mM), in contrast to $20-100 \mu \mathrm{M}$ bromide, $0.1-0.6 \mu \mathrm{M}$ iodide and 20-120 $\mu \mathrm{M}$ thiocyanate. Time course $\mathrm{H}_{2} \mathrm{O}_{2}$-decay plots for MPOcatalyzed oxidation of $\mathrm{Cl}^{-}$, at a selected normal plasma level $(100 \mathrm{mM})$, in presence of increasing $\mathrm{NO}_{2}$ concentrations were examined by continuous amperometric monitoring of $\mathrm{H}_{2} \mathrm{O}_{2}$ consumption (Fig. 1 (b-e)). Monophasic plots prevail for $\mathrm{NO}_{2}{ }^{-}$concentrations $0-20 \mu \mathrm{M}$, accompanied with a drop of rate of consumption of $\mathrm{H}_{2} \mathrm{O}_{2}$ from 1.5 to $0.75 \mu \mathrm{M} / \mathrm{s}$. As $\mathrm{NO}_{2}{ }^{-}$concentrations exceed 25 $\mu \mathrm{M} / \mathrm{s}$, plots became biphasic and accompanied with further decrease of consumption rates from both steps. Rate results and reaction times are summarized in Table 1.

Results in Table 1 show that $\mathrm{NO}_{2}{ }^{-}$inhibited both rapid and slow steps. Rates of first step were reduced from 1.5 (absence of nitrite) to $0.30 \mu \mathrm{M} / \mathrm{s}\left(100 \mu \mathrm{M} \mathrm{NO}_{2}{ }^{-}\right)$, while rates of second step were reduced from $0.30\left(25 \mu \mathrm{M} \mathrm{NO}_{2}{ }^{-}\right)$to 0.13 to $\mu \mathrm{M} / \mathrm{s}$ $\left(100 \mu \mathrm{M} \mathrm{NO}_{2}^{-}\right)$. Total $\mathrm{H}_{2} \mathrm{O}_{2}$-consumption time increased from 6 to $60 \mathrm{~s}$. Since lower rate values are larger than blank values $(0.1$ and $0.03 \mu \mathrm{M} / \mathrm{s})$, nitrite is considered a weak inhibitor to MPO catalytic activity towards oxidation of chloride.

To study the effect of $\mathrm{Cl}^{-}$concentration on $\mathrm{NO}_{2}{ }^{-}$inhibition of the reaction we preincubated the reaction with $100 \mu \mathrm{M} \mathrm{NO}_{2}{ }^{-}$and varied concentrations of $\mathrm{Cl}^{-}$. Time course plots of consumption of $\mathrm{H}_{2} \mathrm{O}_{2}$ were biphasic and similar to those in Fig. 1 with a decrease in both rates by decreasing $\mathrm{Cl}^{-}$concentration; rate results and reaction times are summarized in Table 2. Total $\mathrm{H}_{2} \mathrm{O}_{2}$-consumption time increased from $60 \mathrm{~s}$ to $240 \mathrm{~s}$. At $5 \mathrm{mM} \mathrm{Cl}^{-}(20$ times lower than normal plasma concentration) and $100 \mu \mathrm{M} \quad \mathrm{NO}_{2}^{-}$(25 times lower than normal plasma concentration) calculated rates were 0.12 and $0.04 \mu \mathrm{M} / \mathrm{s}$ from first and second steps, respectively. Since, these values are similar to blank values we assume that complete inhibition could occur under conditions far from physiological concentrations of $\mathrm{Cl}^{-}$and $\mathrm{NO}_{2}^{-}$. 
Table 1. Relative rates and reaction times for MPO-catalyzed reaction of hydrogen peroxide with selected physiological concentrations of halides and thiocyanate, at varied concentrations of nitrite*.

\begin{tabular}{|c|c|c|c|}
\hline Nitrite $(\mu \mathrm{M})$ & First rate $(\mu \mathrm{M} / \mathrm{s})$ & Second rate $(\mu \mathrm{M} / \mathrm{s})$ & Reaction time (s) \\
\hline \multicolumn{4}{|c|}{ Chloride (100 mM) } \\
\hline 0.0 & 1.5 & - & 6 \\
\hline 20 & 0.75 & - & 12 \\
\hline 25 & 0.50 & 0.28 & 28 \\
\hline 50 & 0.40 & 0.18 & 42 \\
\hline 100 & 0.30 & 0.14 & 60 \\
\hline \multicolumn{4}{|c|}{ Bromide $(60 \mu \mathrm{M} / \mathrm{s})$} \\
\hline 0.0 & 1.0 & - & 10 \\
\hline 0.50 & 0.70 & 0.14 & 30 \\
\hline 1.0 & 0.50 & 0.08 & 62 \\
\hline 5.0 & 0.20 & 0.04 & 220 \\
\hline 10 & 0.10 & 0.03 & $>250$ \\
\hline \multicolumn{4}{|c|}{ Iodide $(10 \mu \mathrm{M} / \mathrm{s})$} \\
\hline 0.0 & 1.2 & - & 8 \\
\hline 0.5 & 0.60 & 0.10 & 60 \\
\hline 1.0 & 0.40 & 0.05 & 190 \\
\hline 2.0 & 0.20 & 0.03 & $>250$ \\
\hline 4.0 & 0.10 & 0.03 & $>250$ \\
\hline \multicolumn{4}{|c|}{ Thiocyanate $(50 \mu \mathrm{M} / \mathrm{s})$} \\
\hline 0.0 & 1.0 & - & 10 \\
\hline 20 & 0.70 & 0.14 & 26 \\
\hline 40 & 0.50 & 0.08 & 65 \\
\hline 80 & 0.40 & 0.07 & 105 \\
\hline 100 & 0.35 & 0.06 & 125 \\
\hline
\end{tabular}

* Initial concentrations were $10 \mu \mathrm{M} \mathrm{H}_{2} \mathrm{O}_{2}$ and $50 \mathrm{nM}$ MPO. First rate was calculated over the first $10 \mathrm{~s}$ of the reaction. Second rate was calculated over the period 20-30 s. Results are the average of $(n=4)$.

Table 2. Relative rates and reaction times for MPO-catalyzed reaction of hydrogen peroxide with varied concentrations of chloride, at $100 \mu \mathrm{M}$ nitrite*.

\begin{tabular}{|l|c|c|c|}
\hline Chloride $(\mathrm{mM})$ & First rate $(\mu \mathrm{M} / \mathrm{s})$ & Second rate $(\mu \mathrm{M} / \mathrm{s})$ & Reaction time $(\mathrm{s})$ \\
\hline 5.0 & 0.12 & 0.04 & 240 \\
\hline 10 & 0.14 & 0.06 & 190 \\
\hline 20 & 0.15 & 0.08 & 115 \\
\hline 40 & 0.19 & 0.10 & 90 \\
\hline 80 & 0.23 & 0.12 & 70 \\
\hline 100 & 0.30 & 0.13 & 60 \\
\hline
\end{tabular}

* Initial concentrations were $10 \mu \mathrm{M} \mathrm{H}_{2} \mathrm{O}_{2}$ and $50 \mathrm{nM}$ MPO. First rate was calculated over the first $10 \mathrm{~s}$ of the reaction. Second rate was calculated over the period 20-30 s. Results are average of $(n=4)$. 


\section{Effect of $\mathrm{NO}_{2}^{-}$on MPO-catalytic activity towards oxidation of $\mathrm{Br}^{-}$, I and $\mathrm{SCN}^{-}$}

Even bromide and iodide are not preferred substrates for MPO, their MPO catalyzed oxidation was investigated [42]. Also, it was reported that $\mathrm{SCN}^{-}$is a preferred substrate for MPO and its MPO catalyzed reaction was extensively studied [34,42]. Thus, we extended our study to include for the first time bromide, iodide and thiocyanate.

Initial decay plots (absence of nitrite) were monophasic. As $\mathrm{NO}_{2}{ }^{-}$concentration increased reactions became biphasic. Calculated rates and total $\mathrm{H}_{2} \mathrm{O}_{2}$ consumption times are summarized in Table 1. For bromide, the second step was completely inhibited at $5.0 \mu \mathrm{m} \mathrm{NO}_{2}{ }^{-}$and both steps were completely inhibited at $10 \mu \mathrm{m} \mathrm{NO}{ }_{2}^{-}$. For iodide, the second step was completely inhibited at $2.0 \mu \mathrm{m} \mathrm{NO}_{2}{ }^{-}$ and both steps were completely inhibited at $4.0 \mu \mathrm{m} \mathrm{NO}{ }_{2}^{-}$. These results imply that nitrite is a strong inhibitor to their MPO catalyzed oxidation reactions. In contrast to bromide and iodide, nitrite is a weak inhibitor to MPO catalyzed oxidation of thiocyanate. At $100 \mu \mathrm{m} \mathrm{NO}_{2}^{-}$(double of initial concentration of $\mathrm{SCN}^{-}$) rates of consumption of $\mathrm{H}_{2} \mathrm{O}_{2}$ were 0.35 and $0.06 \mu \mathrm{m} / \mathrm{s}$ from both steps, respectively.

\section{Discussion}

Our major objective in this study was to explore the importance of electrochemical measurements in enzyme kinetics. We acknowledge that other non-electrochemical measurements are still required to reach a complete kinetic model.

Assessment of MPO-catalytic activity towards oxidation of halides and pseudo halides is a complex and multifunctional process [24,37]. MPO catalytic activity is dependent on initial concentrations of MPO, $\mathrm{H}_{2} \mathrm{O}_{2}$ and halide or pseudo halide, $\mathrm{H}_{2} \mathrm{O}_{2}$ to MPO concentration ratio and order of addition.

Because MPO compound I formation rate is slower than the 2e oxidation of halides or thiocyanate, compound I cannot be detected during steady state catalysis $[20,44,45]$. Thus, the rate of formation and accumulation of compound II will be a measure of decrease in MPO catalytic activity.

In this study, we presented a comprehensive electrochemical evidence that nitrite inhibits the MPO catalytic activity towards oxidation of halides and thiocyanate. Our results show for the first time that nitrite is a strong inhibitor for oxidation of iodide and bromide and a weak inhibitor for oxidation of thiocyanate and chloride.

Burner et al. studied the mechanism of reaction of MPO with nitrite [32]. They investigated the reaction of compound I and compound II with nitrite under presteady state conditions by using sequential mixing stopped-flow measurements. They concluded that nitrite is oxidized by two one-electron steps in the MPO peroxidase cycle.

$$
\underset{\text { Compound I }}{\text { MPO-Fe(IV) }}=\mathrm{O}^{\cdot+\pi}+\mathrm{H}^{+}+\mathrm{NO}_{2}^{-} \rightarrow \underset{\text { Compound II }}{\mathrm{MPO}-\mathrm{O}(\mathrm{IV})=\mathrm{O}}+\mathrm{NO}_{2}
$$




$$
\mathrm{MPO}-\mathrm{Fe}(\mathrm{IV})=\mathrm{O}+\mathrm{H}^{+}+\mathrm{NO}_{2}^{-} \rightarrow \mathrm{MPO}-\mathrm{Fe}(\mathrm{III})+\mathrm{NO}_{2} \cdot+\mathrm{H}_{2} \mathrm{O}
$$

The second-order rate constant of reduction of compound I to compound II (Eq. 5) by nitrite is $2.0 \times 10^{6} \mathrm{M}^{-1} \mathrm{~s}^{-1}$ and reduction of compound II to native MPO (Eq. 6) is $5.5 \times 10^{2} \mathrm{M}^{-1} \mathrm{~s}^{-1}$. These results indicate that nitrite inhibits the reaction by formation and accumulation of compound II.

Other pre-steady state studies with stopped-flow monitoring were conducted to study MPO catalytic activity in presence of chloride, bromide, iodide and thiocyanate [23, 25, 35, 42-45]. Reported second-order rate constants varied from $1 \times 10^{7}$ to $4.3 \times 10^{7} \mathrm{M}^{-1} \mathrm{~s}^{-1}$ for formation of compound I. Second-order rate constants for two electron oxidation of halides and thiocyanate by compound I were from $2.5 \times 10^{4}$ (physiological concentration) to $4.7 \times 10^{6}$ (lower concentration) for chloride, $1.1 \times 10^{6} \mathrm{M}^{-1} \mathrm{~s}^{-1}$ for bromide, $7.2 \times 10^{6} \mathrm{M}^{-1} \mathrm{~s}^{-1}$ for iodide and $9.6 \times 10^{6} \mathrm{M}^{-1} \mathrm{~s}^{-1}$ for thiocyanate. Second-order rate constant for formation of compound II from reaction of compound I and hydrogen peroxide was from $3.5 \times 10^{4}$ to $8.2 \times 10^{4} \mathrm{M}^{-1} \mathrm{~s}^{-1}$. Variations between reported results are expected and are mainly attributed to initial conditions and advance of employed instrumentation. Thus, for steady-state studies of inhibition effect of nitrite on MPO catalytic activity towards oxidation of halides and thiocyanate, initial concentrations should be optimized that, in absence of nitrite, complete decay of initial $\mathrm{H}_{2} \mathrm{O}_{2}$ signal should occur without any accumulation of compound II.

Increasing concentrations of nitrite inhibits the MPO catalyzed oxidation of halides and thiocyanatate by initially decreasing the rate of initial rapid step followed by altering the reaction to biphasic and in-sequence decreasing rates of both rapid and slow steps.

Inhibition effect of $\mathrm{NO}_{2}{ }^{-}$on MPO catalytic activity was observed in all studied halides and thiocyanate. Inhibition increases upon increasing nitrite concentration and was largest for iodide and bromide. Complete inhibition occurred at nitrite concentrations of $4.0 \mu \mathrm{M}$ for iodide, $10 \mu \mathrm{M}$ for bromide and partial inhibition was observed for chloride and thiocyanate even at $100 \mu \mathrm{M}$ nitrite.

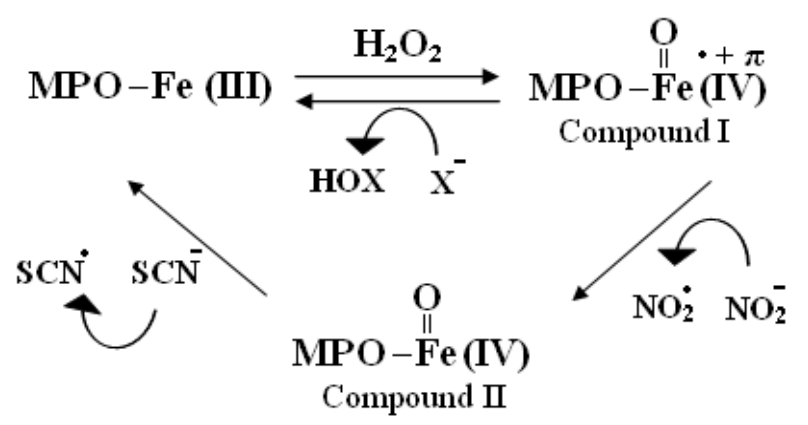

Figure 2. Simple kinetic model representing the inhibitory effect of $\mathrm{NO}_{2}{ }^{-}$.

Very high physiological concentration of chloride relative to other halides and thiocyanate has contributed to this effect. Complete inhibition occurred approximately at $5.0 \mathrm{mM} \mathrm{Cl}^{-}$(twenty times lower than physiological level) and $100 \mu \mathrm{M} \mathrm{NO}_{2}^{-}$(twenty five times larger than physiological concentration) (Table 
2). Thiocyanate and bromide have approximately the same physiological levels and rates of $2 \mathrm{e}$ oxidation by compound $\mathrm{I}$. Thus, thiocyanate is expected to follow bromide of being strongly inhibited by nitrite. It was documented that thiocyanate modulates catalytic activity of MPO by being oxidized via $2 \mathrm{e}$ and two 1e mechanisms. Thiocyanate reduces compound II to ground state MPO with a second-order rate constant of $1 \times 10^{4} \mathrm{M}^{-1} \mathrm{~s}^{-1}$ (eq. 7) [24].

$\mathrm{MPO}-\mathrm{Fe}(\mathrm{IV})=\mathrm{O}+\mathrm{H}^{+}+\mathrm{SCN}^{-} \rightarrow \mathrm{MPO}-\mathrm{Fe}(\mathrm{III})+\mathrm{SCN}+\mathrm{H}_{2} \mathrm{O}$

A general kinetic scheme describing how $\mathrm{NO}_{2}^{-}$inhibits the MPO-catalyzed oxidation of halides and thiocyanate is illustrated in Fig. 2. In absence of nitrite, initial conditions were optimized that complete decay of $\mathrm{H}_{2} \mathrm{O}_{2}$ occurs through $2 \mathrm{e}$ oxidation without formation of compound II (enzyme is swinging between compound I and native MPO and working in maximum activity) which was represented by the initial rapid and monophasic step $(<10 \mathrm{~s})$. In presence of increasing concentrations of nitrite, part of compound I is reduced to compound II (Eq. 5) by causing the enzyme to work at fraction of maximum activity, which was represented by the biphasic character of the amperometrically monitored $\mathrm{H}_{2} \mathrm{O}_{2}$-decay signal.

\section{Conclusions}

A reliable electrochemical method has been employed for the study of inhibitory effect of nitrite on MPO-catalytic activity towards oxidation of halides and thiocyanate. Sensitivity of the method was demonstrated by presenting the monophasic and biphasic character of the amperometrically monitored $\mathrm{H}_{2} \mathrm{O}_{2}$ decay plots and the ability to distinguish between two different rates in the first $30 \mathrm{~s}$ of the reaction. Selectivity of the method was verified by monitoring $\mathrm{H}_{2} \mathrm{O}_{2}$ decay plots with reaction times between $6 \mathrm{~s}$ and $>250 \mathrm{~s}$ without significant interferences from pre-incubated reactants and produced hypohalous acids.

Our results demonstrated that under physiological concentrations of halides and thiocyanate, nitrite is a strong inhibitor to MPO-catalyzed oxidation of iodide and bromide. Nitrite is a weak inhibitor of MPO-catalyzed oxidation of chloride and thiocyanate, which is largely due to high physiological concentration of chloride and reduction of compound II to native MPO by thiocyanate.

Limitations of electrochemical measurements in enzyme kinetics are mainly due to relatively long response time of available electrodes (seconds). For example, in our study the rapid step (first $10 \mathrm{~s}$ of the reaction) needs to be resolved and this could be done by modifying response time of $\mathrm{H}_{2} \mathrm{O}_{2}$-biosensor to milliseconds rather than seconds. Additionally, the development of MPO-biosensor will solve the puzzle of MPO partitioning between native enzyme and intermediates during steady state catalysis. The ultimate goal of success of electrochemical measurements in enzyme kinetics is the ability to perform pre-steady state catalysis with electrochemical detection. 


\section{Acknowledgments}

This work was done at Department of Obstetrics and Gynecology, School of Medicine, Wayne State University, Detroit, MI, USA. The principal author would like to thank Jordan University of Science and Technology for financing research sabbatical to conduct this study.

\section{References}

1. S. Galijasevic, G. Saed, M. Diamond, H. Abu-Soud, PNAS 100 (2003) 14766. 10.1073/pnas.2435008100

2. L. Ignarro, Ann. Rev. Pharmacol. Toxicol. $30 \quad$ (1990) 535. 10.1146/annurev.pa.30.040190.002535

3. S. Moncada, R. Palmer, E. Higgs, Pharmacol. Rev. 43 (1991) 109.

4. S. Vincent, Prog. Neurobiol. 42 (1994) 129. 10.1016/0301-0082(94)90023-X

5. E. Anggard, Lancet 343 (1994) 1199. 10.1016/S0140-6736(94)92405-8

6. J. Beckman, W. Keppenol, Am. J. Physiol. 271 (1996) C1424.

7. L. Ignarro, J. Fukuto, J. Griscavage, N. Rogers, R. Byrns, Proc. Natl. Acad. Sci. USA 90 (1993) 8103.

8. D. Torre, G. Ferrario, F. Sperenza, A. Orani, G. Fiori, C. Zeroli, J. Clin. Path. 49 (1996) 574. 10.1136/jcp.49.7.574

9. A. Farrell, D. Blake, R. Palmer, S. Moncada, Am. Rheum. Dis. 51 (1992) 1219. 10.1136/ard.51.11.1219.

10. A. Leone, P. Francis, R. Rhodes, S. Monkada, Biochem. Biophys. Res. 200 (1994) 951. 10.1006/bbrc.1994.1542

11. T. Ueda, T. Maekawa, D. Sadamitsu, S. Oshita, K.Ogino, K. Nakamura, Electrophoresis 16 (1995) 1002. 10.1002/elps.11501601167

12. B. Gaston, J. Reilly, J. Drazen, J. Fackter, P. Ramdey, D. Arnelle, M. Mollins, D. Sugrabaker, C. Chee, D. Singel, J. Loscalazo, J. Stamler, Proc. Natl. Acad. Sci. USA 90 (1993) 10957.

13. L. Green, D. Wagner, J. Glokowiski, P. Skipper, J. Wishnok, S. Tannenbaum, Anal. Biochem. 126 (1982) 131. 10.1016/0003-2697(82)90118-X

14. S. Klebanoff, J. Leukocyte Biol. 77 (2005) 598. 10.1189/jlb.1204697

15. M. Belding, S. Klebanoff, G. Ray, Science $167 \quad$ (1970) 195. 10.1126/science.167.3915.195

16. S. Kimura, M. Ikeda-Saito, Proteins 3 (1988) 113.

17. E. Jong, W. Henderson, S. Klpanoff, J. Immunol. 124 (1980) 1378.

18. S. Weiss, S. Test, C. Eckman, D. Roos, S. Regiani, Science 234 (1986) 200. 10.1126/science. 3018933

19. S. J. Klebanoff, A. M. Waltersdroph, H. Rosen, Methods Enzymol. 105 (1984) 399. 10.1016/S0076-6879(84)05055-2

20. A. J. Kettle, C. C. Winterbourn, Redox. Rep. 3 (1997) 89-107.

21. J. Hurst, in Peroxidases in Chemistry and Biology, J. Everse, K. Everse, M. Grisham, Eds., Vol. 1, CRC. Press, Boca Raton-Fl, 1991. p. 37.

22. L. Marquez, J. Huang, H. Hunford, Biochemistry 33 (1994) 1447. 10.1021/bi00172a022

23. L. Marquez, H. Dunford, H. van Wart, J. Biol. Chem. 265 (1990) 5666.

24. Y. Tahboub, S. Galijasevic, M. Diamond, H. Abu-Soud, J. Biol. Chem. 280 (2005) 26129._10.1074/jbc.M503027200 
25. S. Galijasevic, I. Abdulhamid, H. Abu-Soud, Free Radic. Biol. Med. 44 (2008) 1570. 10.1016/j.freeradbiomed.2008.01.003

26. H. Shibata, Y. Kono, S. Yamashita, Y. Sawa, H. Ochiai, K. Tanaka, Biochim. Biophys. Acta 1230 (1995) 45. 10.1016/0005-2728(95)00031-D

27. A. vander Vliet, J. Eiserich, C. O'Neill, B. Halliwell, C. Cross, Arch. Biochem. Biophys. 319 (1995) 341. 10.1006/abbi.1995.1303

28. E. Monzani, R. Roncone, M. Galiano, W. Koppenol, L. Casella, Eur. J. Biochem. 271 (2004) 895. 10.1111/j.1432-1033.2004.03992.x

29. A. vander Vliet, J. Eiserich, B. Halliweel, C. Cross, J. Biol. Chem. 272 (1997) 7617. 10.1074/jbc.272.12.7617

30. J. Eiserich, C. Cross, A. Jones, A. vander Vliet, J. Biol. Chem. 271 (1996) 19199. 10.1074/jbc.271.32.19199

31. C. van Dalen, C. Winterbourn, R Santhilmohan, A. Kettle, J. Biol. Chem. 275 (2000) 11638. 10.1074/jbc.275.16.11638

32. U. Burner, P. Furtmuller, A. Kettle, W. Koppenal, C. Obinger. J. Biol. Chem. 275 (2000) 20597. 10.1074/jbc.M000181200

33. A. Kettle, C. Winterbourn, Methods Enzymol. 233 (1994) 502. 10.1016/S00766879(94)33056-5

34. C. van Dalen, M. Whiterhouse, C. Winterbourne, A. Kettle, Biochem. J. 327 (1997) 487.

35. A. Kettle, C. Winterbourne, Biochemistry 40 (2001) 10204. 10.1021/bi010940b

36. J. Wang, Electroanalysis 17 (2005) 7. 10.1002/elan.200403113

37. www.wpiinc.com

38. R. Rakita, R. Michel, H. Rosen, Biochemistry 29 (1990) 1075. 10.1021/bi00456a033

39. R. Wever, H. Plat, M. Hamers, FEBS Lett. 123 (1981) 327.

40. K. Agner, Acta. Chem. Scand. 17 (1963) S332.

41. H. Hoogland, H. Dekker, C. van Riel, A.van Kuilenburg, A. Muijsers, R. Wever, Biochimica et Biophysica Acta 955 (1988) 337. 10.1016/0167-4838(88)90213-0

42. P. Furtmuller, C. Obinger, Y. Hsuanyu, H. Dunford, Eur J. Biochem. 267 (2000) 5858. 10.1046/j.1432-1327.2000.01491.x

43. P. Furtmuller, U. Burner, C. Obinger, Biochemistry 37(1998) 17923. 10.1021/bi9818772

44. H. Dunford, Y. Hsuanyu, Biochem. Cell Biol. 77 (1999) 449. 10.1139/bcb-77-5-449

45. J. Arnold, P. Furtmuller, C. Obinger, Redox Rep. 8 (2003) 179. $10.1179 / 135100003225002664$ 